Article

\title{
Impact of Climate Change on Cultivar Choice: Adaptation Strategies of Farmers and Advisors in German Cereal Production
}

\author{
Janna Macholdt * and Bernd Honermeier \\ Department of Agronomy, Institute of Agronomy and Plant Breeding I, Justus-Liebig-University Giessen, \\ Gießen 35392, Germany; janna.c.macholdt@agrar.uni-giessen.de \\ * Correspondence: janna.c.macholdt@agrar.uni-giessen.de; Tel.: +49-641-993-7475
}

Academic Editor: Mick P. Fuller

Received: 19 May 2016; Accepted: 19 July 2016; Published: 22 July 2016

\begin{abstract}
The objective of this study is to understand which requirements for cereal cultivars-with regard to climate change adaptation - are in demand by farmers and advisors, and to clarify whether there are any differences in their assessments. A comparative survey was used to collect data from 410 farmers and 114 advisors in Germany. The majority of both farmers and advisors reported perceivable effects of climatic change on plant production. The increase in droughts and hot spells, the increased incidence of torrential rain, and mild winters were mentioned as the main effects of climate change. For climate change adaptation, the farmers and advisors mostly relied on a locally-adapted cultivar selection. It is estimated that eco-stability, grain yield, resistance to lodging and drought tolerance are important cultivar properties. In the study, farmers and advisors equally pointed out the need for additional cultivar evaluation according to eco-stability. Finally, only minor differences regarding farmers' and advisors' assessments were found within the study. The outcome of this research points to the need of implementing farmers' demands in cultivar recommendations. For example, an impartial assessment of cultivars' eco-stability could help support the choice of cultivars and reduce the growing risks in cereal production with regard to climate change.
\end{abstract}

Keywords: survey; plant production; cultivar requirements; cultivar type; hybrid cultivars; eco-stability

\section{Introduction}

Changing climatic conditions play a significant role in shaping agricultural production, at present and in future [1,2]. One of the major challenges for farmers facing changing climatic conditions and increasing climatic variability is to identify adaptation strategies and incorporate them into their cropping systems [3,4]. Relevant literature also confirms climatic changes and, specifically, that climatic variability has increased in Germany over past decades [5,6], particularly in areas of sandy soil in the drier Northeastern region of Germany [7]. Based on climate models, it has been predicted that Germany, among other things, will be subject to generally increasing temperatures, decreasing summer precipitation, and an increase in precipitation during winter months [8].

Against this background, there is a need to understand how farmers might cope with climatic variability and implement adaptation strategies in cereal production [9]. There is an increasing number of studies that investigate farmers' beliefs about climate change, their concerns (risk perception) related to its effects, and their willingness to adapt to it [10]. Farmers' concerns surrounding climate change refers to the potentially negative effect it could have on agricultural productivity [11,12], like drought stress or increased risk of pests and diseases [13]. Furthermore, the effect of climate change on plant production depends partially on the inner attitude of farmers to adapt to climatic variations 
by developing appropriate strategies $[14,15]$. Adaptation strategies might affect changing farming methods such as tillage practices, irrigation, planting date, earliness, crop protection methods, fertilizer control, and cultivar choice [16-18]. Thus, climate change adaptation in plant production is a broad and complex topic. Different studies found that farmers are adopting various strategies depending on their site conditions, and that cultivar choice is one of their primary mechanisms of adapting crop production to changing climatic conditions [19-21]. For this reason, farmers' decision-making underlines the significant adaptation potential of cultivar choice.

In Germany, several hundred cereal cultivars with different features and suitability for cultivating are provided for on-farm cultivar choice [22]. Recently registered cultivars embody achievements in genetic advance or breeding improvements, and make them available for agronomic practice. Cereal yields have increased considerably in the last decades, primarily on the basis of plant breeding progress [23-25]. Plant breeding plays a very important role in addressing future climatic challenges in crop production [26]. Developing cultivars that tolerate specific climatic impacts requires a comprehensive understanding of genotype-environment interaction. Cultivars can react in diverse ways to variable and stressing growing conditions [27]. A cultivar is considered to be more eco-stable if it has a low level of cultivar-environment interaction (unpredictable variables) [28-30]. Here, high eco-stability represents marginal deviations from the general response of cultivars to growing conditions. These kind of eco-stability evaluations allow researchers to identify stress-tolerant cultivars for use under diverse growing conditions and help to secure yield in crop production under changing climate [31,32]. Several recent studies underline the high demand for eco-stable cultivars in adapting to climate change $[20,33]$. Plant breeding progress, especially developing eco-stable cultivars, in addition to agronomic adaptation will be required to minimize the yield losses attributed to climate change [34].

These considerations led to the subject of this paper. The chosen topic of this study is cultivar choice, as one of the most important areas of crop management with great adaptation potential that could be enacted through specific and rapid implementation of plant breeding progress in on-farm crop production. In particular, the focus is on cultivar choice in cereal production, because of its importance in Germany and worldwide. The present study endeavors to examine how farmers are coping with the effects of contemporary climatic change on cereal production, putting a clear emphasis on adaptation through cultivar selection. Further, the subject of eco-stability in the course of cultivar choice will be under special consideration. The major objectives of this paper are first to investigate the demand for specific requirements for cereal cultivars with respect to climate change adaptation farmers and agricultural advisors; and second, to clarify the hypothesis as to whether there are any differences in the context of this assessment between farmers and advisors.

\section{Materials and Methods}

\subsection{Study Area}

In the study area of Germany, the temperate climate is characterized by an average annual temperature of around $8.2^{\circ} \mathrm{C}$ and average precipitation of about $750 \mathrm{~mm}$ per year [35]. Farming is practiced on roughly 287,000 farms covering 16.7 million hectares, representing nearly one half of Germany's total land area [36]. About half of the farms are specialized in plant production and cultivate grain crops on 6.5 million hectares [37]. After France, Germany is the second most important grain producer in the European Union, with about 48 million tons produced in 2015 [36].

The following information is published in the German situation report [38]. Germany's chief cultivated cereals are wheat and barley. The average yield of winter wheat is about $86.8 \mathrm{dt} \cdot \mathrm{ha}^{-1}$ on an area of 3.22 million hectares. Barley is cultivated on about 1.3 million hectares, with an average yield of $77.3 \mathrm{dt} \cdot \mathrm{ha}^{-1}$ for winter barley and $59.8 \mathrm{dt} \cdot \mathrm{ha}^{-1}$ for spring barley, respectively. The area for growing triticale is about 418 thousand hectares, on which an average of $71.1 \mathrm{dt} \cdot \mathrm{ha}^{-1}$ is harvested. The production of rye is locally focused in the middle and eastern part of Germany, on a total of 580,000 hectares and at an average yield of $61.2 \mathrm{dt} \cdot \mathrm{ha}^{-1}$. The production of oats and spelt has less 
importance, at 124,000 hectares for oat (averaging $50.6 \mathrm{dt} \cdot \mathrm{ha}^{-1}$ ) and nearly 50,000 hectares for spelt (yield statistics not available).

For cereal production there is a broad assortment of cultivars and cultivar types available, approved and evaluated by the German Federal Office of Plant Cultivars and state field trials offices. At present, from among these authorized cultivars, farmers can choose between 187 wheat, 144 barley, 47 triticale, 43 rye, 35 oat and 11 spelt cultivars [22]. Furthermore, official and private agricultural advisors support farmers' cultivar choice with regional and site-specific information, as well as additional experimental results with special selected cultivars.

\subsection{Survey}

The broad-based study was carried out on the basis of a standardized online questionnaire in order to address a nationwide target group, achieve high participation and to ensure the comparability of the results [39]. Furthermore, the study was adjusted to gain qualitative information and subjective opinions of German farmers and advisors in cereal production. The study took place from December 2015 to March 2016. The target groups were farmers and agricultural advisors that have worked in cereal production for several years.

The questionnaire was structured in the following way: In the first section, some information about the participants and the site conditions of their cereal production, such as soil quality and area under cultivation, were elicited. In the second part, information about the farmers' and advisors' beliefs regarding climate change, the effect on plant production, and their attitudes towards adaptation strategies were collected. In the following subsections, farmers and advisors were asked for their assessment of special cultivar properties separately per crop (wheat, barley, triticale, rye, oat and spelt). In addition, the questionnaire included questions about the decision-making processes of farmers and their preferred source of information on the issue of cultivar choice.

Farmers' and advisors' perceptions were elicited using open-ended and closed questions, in combination with Likert scales as well as multiple-option questions. The survey was based on a standardized computer-based questionnaire and was realized online via "Q-Set". The farmers were invited to participate in the online survey through social media groups in the field of plant production and agronomy. In addition, they were invited through mailing lists of regional farmers and seeds associations as well as personal invitations. A sample of 410 farmers and 114 advisors supplied fully-completed questionnaires, which formed the respondents for the study. The majority of participating farmers and advisors have had more than seven years' farming experience. The main type of farm is conventional field cropping, (cereals, oilseeds, silage, etc.) with the minority practicing organic agriculture. The professional affiliations of the 114 advisors interviewed can be summarized as follows: research organizations $(n=22)$, plant breeding companies $(n=47)$, private agronomy consulting companies $(n=18)$, regional agriculture departments and federal agencies $(n=27)$. The distribution of participants is nearly nationwide- -11 of the 16 federal states of Germany are represented evenly in this study, but there were no respondents from the smaller states of Berlin, Bremen, Hamburg, Saarland and Rheinland-Pfalz.

The descriptive analysis (frequency distribution and percentages) was performed with IBM SPSS Statistics 23 software (IBM Corporation, New York, NY, USA). The results only apply in connection with the study and should not be generalized, because of low statistical certainty [40]. It should be noted that there is often an issue of relatively low representativeness in web-based surveys as well as a problem in defining the sampling frame or response rate [41]. Another point is that the testing environment of web-based designs could not be verified, which might also be seen as an advantage in not influencing the respondents [42]. Furthermore, high dropout rates, non-reliable statements, and multiple entries represent a potential source of errors in online surveys [43]. For this reason, every completed questionnaire was checked individually, verifying the coherence and quality. Additionally, there was a high dropout rate of $50 \%$ - of those that began to complete this questionnaire, only half of 
them actually finished the survey. To increase the data quality, for the evaluation, the entire dataset was checked for duplicates and only fully-completed questionnaires were considered.

\section{Results}

\subsection{Perception of Climatic Variations in Ceral Production}

For the present study, most of the respondents acknowledge climate change. The first question was "Have you perceived climatic changes that you attribute to global climate change, in German cereal production?" The results show that $85 \%$ of the farmers and $90 \%$ of the advisors (Table 1 ) have perceived climatic variations which seem to have an effect on cereal production. Only $12 \%$ and $8 \%$ of the respective respondents have observed no climatic changes and only a small part abstained.

Table 1. Perception of climate change in cereal production.

\begin{tabular}{ccc}
\hline Response Option & Farmers $^{\mathbf{1}} \mathbf{( \% )}$ & Advisors $^{\mathbf{2}} \mathbf{( \% )}$ \\
\hline Yes & 85 & 90 \\
No & 12 & 8 \\
Not specified & 4 & 2 \\
\hline \multicolumn{2}{r}{${ }^{2}$ Farmers $n=494 \cdot{ }^{2}$ Advisors $n=98$}
\end{tabular}

The next question was about "Which kind of increasing effects (2) and consequences (3) of climate change have affected you so far?" The farmers surveyed evaluated the increasing effects of climate change in cereal production as follows: The majority of respondents mentioned an increased frequency of mild winters, drought, hot spells and torrential rain (Table 2). The effects of UV-stress and soil erosion were only mentioned with minor relevance. The results showed a similar grading among farmers and advisors. Furthermore, yield variability, incidence of disease as well as loss of yield and quality were ranked (in that order) by farmers and advisors equally as the main consequences of climate change for cereal production (Table 3).

Table 2. Perception of increasing effects of climate change in cereal production.

\begin{tabular}{ccc}
\hline Response Option $^{\mathbf{1}}$ & Farmers $^{\mathbf{2}} \mathbf{( \% )}$ & Advisors $^{\mathbf{3}} \mathbf{( \% )}$ \\
\hline Mild winters & 21 & 20 \\
Drought & 21 & 20 \\
Hot spells & 16 & 16 \\
Torrential rain events & 15 & 15 \\
Growing season (prolonged) & 12 & 12 \\
Thunderstorms Late frost & 8 & 12 \\
Ultraviolet radiation stress & 5 & 5 \\
Soil erosion & 2 & 2 \\
\hline
\end{tabular}

${ }^{1}$ Multiple answers possible; ${ }^{2}$ Farmers $n=494 ;{ }^{3}$ Advisors $n=98$.

Table 3. Perception of consequences of climate change for cereal production.

\begin{tabular}{|c|c|c|}
\hline Response Option ${ }^{1}$ & Farmers $^{2}(\%)$ & Advisors ${ }^{3}(\%)$ \\
\hline Yield variability & 27 & 27 \\
\hline Incidence of disease & 21 & 19 \\
\hline Loss of yield & 18 & 16 \\
\hline Loss of quality & 14 & 16 \\
\hline Pest infestation & 12 & 11 \\
\hline Frost damage & 6 & 6 \\
\hline Lodging & 3 & 5 \\
\hline
\end{tabular}

${ }^{1}$ Multiple answers possible; ${ }^{2}$ Farmers $n=494 ;{ }^{3}$ Advisors $n=98$. 


\subsection{Site-Adapted Cultivar Selection}

For cultivar selection in particular, the key question of this study was "Do you believe that you can adapt to the effects of climate change through-leaving aside for now other things-the choice of an appropriate cultivar?". The result, for all crops, was the majority of farmers interviewed affirming this question (Table 4). It can be stated that cultivar choice is an important mechanism with which farmers can adapt to climate change effects-with minor crop-specific differences. In the comments section, the farmers interviewed pointed to alternative adaptation strategies, such as adapting fertilization, irrigation, soil tillage and crop rotation measures. These mentioned alternative strategies were disregarded in this study, but will be the topic of pending empirical studies.

Table 4. Farmers' adaptation through cultivar choice to the effects of climate change in cereal production.

\begin{tabular}{cccc}
\hline Response Option & Frequency & Yes (\%) & No (\%) \\
\hline Wheat & 387 & 83 & 17 \\
Barley & 354 & 82 & 18 \\
Rye & 215 & 76 & 24 \\
Triticale & 225 & 77 & 23 \\
Oats & 186 & 67 & 33 \\
Spelt & 158 & 70 & 30 \\
\hline
\end{tabular}

Congruent to the answers of farmers, the participant group of advisors provided similar results regarding cultivar choice (Table 5). The greater part of advisors believed the effects of climate change can be mitigated/addressed through the choice of appropriate cultivar. Furthermore, crop-specific differences were stated, so that affirmation of the question was stated in descending order from wheat to spelt. Here again, a large portion of respondents did not make any entries for the crops rye, triticale, oats or spelt.

Table 5. Advisors' adaptation through cultivar choice to the effects of climate change in cereal production.

\begin{tabular}{cccc}
\hline Response Option & Frequency & Yes (\%) & No (\%) \\
\hline Wheat & 84 & 83 & 17 \\
Barley & 68 & 89 & 11 \\
Rye & 55 & 77 & 23 \\
Triticale & 55 & 77 & 23 \\
Oat & 44 & 54 & 46 \\
Spelt & 42 & 61 & 39 \\
\hline
\end{tabular}

\subsection{Use of Transgenic Cultivars}

Farmers and advisors were asked, respectively "Would you recommend growing genetically modified cultivars, if they were legal and benefits could be derived in terms of adapting to climate change?" The results (Table 6) suggest that, as an adaption to climate change, the use of genetically modified cultivars would be an option for $21 \%$ of surveyed farmers-insofar as these were legally permitted in Germany. Twenty-eight percent of respondents were undecided on the use of green gene technology and $50 \%$ of the farmers surveyed were against it. For the participant group of advisors similar results were found. 
Table 6. Possible use of genetically modified cultivars with expected advantages for climate change adaptation.

\begin{tabular}{ccc}
\hline Response Option & Farmers $^{\mathbf{1}} \mathbf{( \% )}$ & Advisors $^{\mathbf{2}} \mathbf{( \% )}$ \\
\hline Yes & 21 & 26 \\
Perhaps & 28 & 15 \\
No & 50 & 57 \\
Not specified & 1 & 2 \\
\hline \multicolumn{2}{c}{}
\end{tabular}

\subsection{Comparison of Cultivar Types}

The next section referred to the comparison of different cultivars and the question was as follows "Do you think that hybrid cultivars offer greater eco-stability and therewith adaption potential regarding climate change?" In the study, the farmers (Table 7) and advisors (Table 8) interviewed confirmed an increased eco-stability of hybrid cultivars compared to other cultivars only with respect to rye. In contrast, for winter wheat, most farmers and advisors even rated the eco-stability of hybrid cultivars as lower compared to line cultivars. Overall, the percentage of abstention was relatively high (up to $61 \%$ ).

Table 7. Farmers' evaluation regarding higher eco-stability of hybrid cultivars compared to other cultivar types.

\begin{tabular}{cccc}
\hline Response Option & Frequency & Yes (\%) & No (\%) \\
\hline Wheat & 264 & 25 & 75 \\
Barley & 291 & 48 & 52 \\
Rye & 220 & 67 & 33 \\
Triticale & 175 & 44 & 56 \\
\hline
\end{tabular}

Table 8. Advisors' evaluation regarding higher eco-stability of hybrid cultivars compared to other cultivar types.

\begin{tabular}{cccc}
\hline Response Option & Frequency & Yes (\%) & No (\%) \\
\hline Wheat & 80 & 15 & 85 \\
Barley & 64 & 28 & 72 \\
Rye & 56 & 78 & 22 \\
Triticale & 48 & 37 & 63 \\
\hline
\end{tabular}

\subsection{Relevance of Different Cultivar Capacities}

The following question was about the relevance of different cultivar capacities. The participants were asked "How important to you are the following different cultivar characteristics-in terms of climate change in cereal production?" (Likert scale). The results were assessed differently (Table 9). The eco-stability of a cultivar was classified by farmers as the most important cultivar feature. This was followed by-in respective rankings of second and third-the characteristics of resistance to lodging and yield potential. The cultivar capacities drought and heat tolerance were assigned a medium importance. For winter hardiness, biotic stress tolerance and earliness the farmers assigned minor priority. 
Table 9. Farmers' evaluation of the relevance of different cultivar capacities with regard to climate change.

\begin{tabular}{cccccccc}
\hline Response Option & Frequency & $\mathbf{1} * \mathbf{( \% )}$ & $\mathbf{2 ( \% )}$ & $\mathbf{3 ( \% )}$ & $\mathbf{4}(\mathbf{\%})$ & $\mathbf{5}(\mathbf{\%})$ & Not Specified (\%) \\
\hline Eco-stability & 462 & 6 & 5 & 5 & 22 & 60 & 2 \\
Resistance to lodging & 462 & 6 & 6 & 12 & 27 & 47 & 1 \\
Yield potential & 462 & 6 & 6 & 11 & 30 & 45 & 2 \\
Drought tolerance & 462 & 7 & 8 & 13 & 28 & 42 & 2 \\
Heat tolerance & 462 & 6 & 14 & 16 & 31 & 30 & 2 \\
Winter hardiness & 462 & 6 & 11 & 19 & 37 & 25 & 3 \\
Biotic stress tolerance & 462 & 4 & 9 & 24 & 38 & 18 & 6 \\
Earliness & 462 & 12 & 14 & 34 & 19 & 19 & 2 \\
\hline
\end{tabular}

* Degree of relevance: 1 = very low, 2 = low, $3=$ intermediate, $4=$ high, 5 = very high.

As with farmers, among the advisors surveyed the three most important cultivar capacities in terms of climate change were eco-stability, yield potential and resistance to lodging. The advisors only rated the relevance of cultivar capacities in a slightly different order (Table 10). They classified the yield potential of a cultivar as the most important feature, followed in descending importance by the characteristics eco-stability and resistance to lodging. The features drought tolerance, winter hardiness and biotic stress tolerance were assigned with a similar and medium importance. Earliness and heat tolerance were referred to as a minor priority by the advisors.

Table 10. Advisors' evaluation to relevance of different cultivar capacities with regard to climate change.

\begin{tabular}{cccccccc}
\hline Response Option & Frequency & $\mathbf{1} * \mathbf{( \% )}$ & $\mathbf{2}(\mathbf{\%})$ & $\mathbf{3 ~ ( \% )}$ & $\mathbf{4}(\mathbf{\%})$ & $\mathbf{5}(\mathbf{\%})$ & Not Specified (\%) \\
\hline Eco-stability & 94 & 6 & 13 & 4 & 28 & 47 & 2 \\
Resistance to lodging & 94 & 9 & 9 & 15 & 21 & 45 & 2 \\
Yield potential & 94 & 6 & 13 & 6 & 21 & 51 & 2 \\
Drought tolerance & 94 & 4 & 34 & 11 & 26 & 23 & 2 \\
Heat tolerance & 94 & 6 & 36 & 11 & 34 & 11 & 2 \\
Winter hardiness & 94 & 6 & 21 & 13 & 34 & 23 & 2 \\
Biotic stress tolerance & 94 & 0 & 11 & 34 & 28 & 23 & 4 \\
Earliness & 94 & 9 & 23 & 23 & 19 & 19 & 6 \\
\hline
\end{tabular}

* Degree of relevance: 1 = very low, 2 = low, 3 = intermediate, 4 = high, 5 = very high.

\subsection{Request for Official Appraisal of Eco-Stability for Cultivars}

The last question was additional and the participants were asked "Would you be interested in getting an official appraisal of eco-stability for cereal cultivars with regard to climate change adaptation?" Currently in Germany there are no official eco-stability appraisals for cultivars given by the German Federal Office of Plant Varieties or other regional authorities. However, on the basis of this study, farmers as well as agricultural advisors would be very interested in such an official and objective evaluation regarding the eco-stability of cereal cultivars (Tables 11 and 12). In particular, for wheat and barley crops, farmers and advisors equally mentioned it would be very important to know. For the questions about the other crops—rye, triticale, oat, and spelt-the respondents gave the potential evaluation of eco-stability slightly less importance and a great part of participants abstained. 
Table 11. Farmers' interest in an official appraisal of eco-stability for cultivars.

\begin{tabular}{cccc}
\hline Response Option & Frequency & Yes (\%) & No (\%) \\
\hline Wheat & 360 & 85 & 15 \\
Barley & 329 & 84 & 16 \\
Rye & 202 & 76 & 24 \\
Triticale & 194 & 78 & 22 \\
Oat & 178 & 71 & 29 \\
Spelt & 170 & 70 & 30 \\
\hline
\end{tabular}

Table 12. Advisors' interest in an official appraisal of eco-stability for cultivars.

\begin{tabular}{cccc}
\hline Response Option & Frequency & Yes (\%) & No (\%) \\
\hline Wheat & 80 & 87 & 13 \\
Barley & 58 & 90 & 10 \\
Rye & 43 & 72 & 28 \\
Triticale & 46 & 78 & 22 \\
Oat & 45 & 77 & 23 \\
Spelt & 44 & 80 & 20 \\
\hline
\end{tabular}

\section{Discussion}

\subsection{Similar Perception of Climate Change Impact}

The majority of farmers and advisors participating in the study perceived noticeable climatic changes relevant to cereal production. In corresponding research concerning farmers' belief about the existence of climate change, similar results could be found $[44,45]$. Furthermore, there are numerous research findings in which climate change has been scientifically proven $[1,2,8,13]$. Although there is scientific evidence for climate change, a significant part of the population in developed countries (within the study $12 \%$ of farmers and $8 \%$ of advisors as well) is skeptical over the issue [46].

In this study, farmers and advisors showed similar perceptions regarding climate change. Even their perceptions on the increasing effects of climate change and its impact on cereal production were listed by advisors and farmers in the same order. The most often mentioned increasing effects were mild winters, drought, hot spells, and torrential rain events. These changing climatic conditions can be confirmed via Germany's long-term weather records [8,35]. The results of the survey indicated that there might be a correlation between the time of this survey and the weather conditions in the current and previous year. In the minds of the surveyed farmers and advisors the weather conditions of the past year (2015) seem to still be relevant—for instance, distinct hot spells and drought in the summer and mild temperatures over the winter. Accordingly, for the most part, they mentioned these effects in the survey.

In addition, evaluations of the consequences of climate change for cereal production were carried out in several studies [21], and align with the statements made by the surveyed farmers and advisors, especially with regard to increasing yield variability, incidence of disease and loss of yield. The extent of consequences due to climate change depends on site conditions, including soil quality/fertility, water-holding capacity, rainfall distribution, solar radiation and rate of evaporation [7]. Moreover, farmers and advisors have observed a lengthening growing season, which is also scientifically verified. An average prolongation by three days per ten years was calculated on the basis of a trend analysis of German climate conditions for the period from 1951 to 2010 [35].

\subsection{Same Direction of Adapting Cultivar Strategy}

Other studies have shown that farmers perceive climate change relevant to crop production and show a great willingness to implement appropriate adaptation measures [10]. For farmers, there are many possibilities to adapt to the climatic changes in crop production through measures, 
for example, in the areas of crop rotation, tillage, crop protection, fertilization, and especially cultivar selection $[47,48]$.

In this study, farmers and advisors both affirmed that adapting their cultivar choice to the effects of changing climatic conditions, especially for wheat and barley crops-the others (rye, triticale, oats, and spelt) were subordinated. In Germany, wheat and barley have greater importance and occupy more growing area than rye, oats, and spelt. Against this background, there is a greater diversity of cultivars for the more relevant crops wheat and barley offered by breeding companies. This fact could be one explanation for the different response frequency in the study. The opportunity of adapting the cultivar choice to the effects of climate change is confirmed by other studies $[23,49,50]$.

Genetic engineering methods (GM) can shorten the development time for new cultivars and offer possibilities for modifying crop tolerance to biotic and abiotic stressors, especially as an adaptation to unfavorable climatic conditions [51]. According to the German Genetic Engineering Act, the use of genetically modified cultivars in Germany is not allowed [52]. Farmers and advisors were asked if they would grow / recommend GM cultivars if they were legal, and yielded benefits related to climate change adaptation. More than half of the respondents rejected the possibility of using genetically modified cultivars, even with expected advantages for climate change adaptation. Again here, only minor differences between the estimations of farmers and advisors were apparent. Relating to farmers' GM perception, these estimates are nearly congruent to the results of previous studies $[49,50,53]$. In addition to the difficulty of estimating environmental risk, the acceptance among consumers is hard to discern. In recent years, experiments with genetically modified plants were repeatedly vandalized. As a result of these protests by opponents of genetic engineering, field trials are often completely fenced off and continuously guarded. For the time being, the use of green genetic engineering remains uncertain, since further research results remain to be seen and national political developments are difficult to estimate.

\subsection{Value of Hybrid Cultivars Depending on Crop Species}

The heterosis effect refers to increased performance, higher efficiency and higher grain yields of hybrids in comparison to other cultivar types [54-56]. Additionally, different studies show some indications that hybrids also might have higher eco-stability-especially under unfavorable site conditions [57-59]. Thus, the observance of crop management and selection of cultivars with greater eco-stability should be afforded a high level of attention. The enhanced eco-stability of hybrids offers a great adaptive potential to increasing abiotic stress in terms of climate change.

The farmers and advisors surveyed rated the value of hybrid cultivars with regard to eco-stability relatively similarly, but differed depending on the crop species-whereby advisors evaluated the differences between the crops more clearly. In the study, farmers and advisors attributed greater eco-stability to certain crops, especially rye. This evaluation corresponds with results of recent studies $[53,58]$ and the widespread use of hybrid lines in German rye production. The advantage of hybrid technology has been firmly established for years. Hence, hybrid lines are available on the market and well-known to farmers and advisors.

Depending on the type of pollination, the heterosis effect of a hybrid wheat cultivar (self-pollinator) is lower than for a hybrid rye cultivar as a cross-pollinator $[53,57,60]$. Moreover, only a few hybrid wheat cultivars are registered by the federal government [22] and their added value, due to weaker heterosis effect as well as potentially greater eco-stability, is often not verifiable in practice [61-63]. The farmers and advisors surveyed confirmed these points, believing that hybrids have lesser eco-stability than line cultivars. In contrast, as a result of current studies, hybrids of winter wheat showed a significantly higher and more stable grain yield in comparison to line cultivars $[57,60]$.

In the study, the lower eco-stability of hybrid barley and triticale cultivars were subjectively evaluated by the advisors and farmers surveyed. Scientific studies demonstrate similar results, in which triticale hybrids had higher yield variability compared to other variety types [64]. In contrast to the perception of the farmers and advisors surveyed, retrospective analysis of official field trials 
showed higher eco-stability of barley hybrids in comparison to line cultivars [65]. It is not surprising that a large proportion of respondents gave no indicative evaluation regarding the eco-stability of hybrids, perhaps due to limited practical and personal experience. In Germany, there are only a few registered hybrid cultivars [22]. The breeding of hybrid cultivars for barley and triticale is at an early stage and not widespread. Furthermore, the heterosis effect for barley (self-pollinator) is similar to wheat, and therefore weaker than for rye [57].

So far, there is limited evidence of ensured higher yield and better eco-stability of hybrid cultivars under practical farming conditions. Only a few breeding companies are focusing work in that field, because of the minor growing importance of barley and triticale in comparison to wheat. But in past decades, hybrid breeding in cereals has taken in greater importance $[65,66]$. The success of hybrid breeding, especially in maize and rye [67], and the use of molecular techniques [68,69], has stimulated further interest.

\subsection{Gradual Differences in Evaluation of Cultivar Capacities}

In the study, farmers and advisors differently evaluated the order particular cultivar capacities. The farmers attributed paramount relevance to the property eco-stability; second-most relevant was resistance to lodging and third-most was yield potential. In different sequence, advisors ranked yield potential as primary - only slightly less was eco-stability followed by resistance to lodging. The answers given by farmers and advisors in the survey were consistent with corresponding research findings, in which the high relevance of eco-stability and yield potential as the main criteria for cultivar choice were confirmed $[31,49,50,53]$. With regard to climate change, the negative impact of weather on plant production will become more pronounced $[7,47]$ and lead to demand for cultivars with greater eco-stability. These eco-stable cultivars would be advantageous in mitigating the risks of agronomic circumstances [31].

Another difference between the ranking by surveyed farmers and advisors concerns the properties' drought tolerance, heat tolerance, winter hardiness, and biotic stress tolerance. To advisors, the characteristics biotic stress tolerance and winter hardiness seem to be more relevant than to farmers. In contrast, farmers ranked the importance of drought and heat tolerance higher than did advisors. In light of climate change, it is understandable that respondents answered in this way. For example, the temperature increase and changes in rainfall distribution forecasted by the Potsdam Institute for Climate Impact Research [8] will make the selection of cultivars with drought and heat tolerance more relevant in Germany. Earliness was ranked by farmers and advisors similarly—in last place-which points to its low relevancy for climate change adaptation.

\subsection{Same Importance of Eco-Stability as Additional Information}

In the study, farmers and advisors alike pointed out the importance and need for additional cultivar evaluation according to eco-stability for climate change adaptation. As mentioned in the previous section, eco-stability is the most important criterion for farmers choosing a cultivar. Farmers would greatly benefit from cultivar scientific estimates of the eco-stability across cultivars. It could support cultivar selection, help them plan more resilient production systems, and offers possible advantages regarding greater and more stable yields and hence profitability. Farmers expressed their need for evaluation of the eco-stability of cultivars especially for wheat and barley crops, subordinated by rye, triticale, spelt and oats. This reflects the dominant economic and spatial roles occupied by wheat and barley in Germany, especially the demand for eco-stable cultivars for cereal production on marginal sites. For advisors, the evaluation of eco-stability across cultivars could provide a consultative advantage in the form of recommendations to farmers on optimized site-specific and climate change-adaptive cultivar-selection strategies. One possibility for an objective appraisal of eco-stability across cultivars could be the implementation of an eco-stability parameter in the annual analysis procedure of the German Federal Office of Plant Varieties [70]. Initial approaches were demonstrated by Michel \& Zenk [61]. The results could be presented in the German Plant 
Cultivar Catalogue [22] and in the official cultivar recommendations at national and regional levels. Both farmers and advisors would have access to this additional and practiced-oriented information regarding the eco-stability of cultivars to support the cultivar-selection process with regard to climate change adaptation [28].

\section{Conclusions}

In answer to the hypothesis of this study, the perception by farmers and advisors regarding the existence and relevance of climate change and adaptive cultivar-selection strategies in cereal production could be confirmed. Furthermore, the respondents listed their agronomic demands for cereal cultivars with regard to climate change adaptation and accentuated the relevance of eco-stable cultivars. In fact, over all test areas there were only slight differences between the assessments of the farmers and advisors surveyed. These differences should not be overstated, but instead, might be evaluated more precisely with further research.

Finally, exchanging experience and information between farmers, advisors, plant breeders, research centers and state authorities should be focused and supported to optimize a comprehensive service and consulting offer [9]. The needs of farmers and advisors should be taken into account, namely, that certain additional and relevant cultivar capacities mentioned, such as eco-stability, drought and heat tolerance should be implemented in plant breeding programs, analysis systems and official cultivar recommendations. The combination of molecular and conventional plant breeding methods could help to identify and develop eco-stable cultivars with desirable genotype-environment-combinations that will be advantageous in cultivation under changing climatic conditions [26]. An agreed upon and standardized method for the evaluation of these eco-stability parameters should be developed to include crop experts in the field of statistics and cultivar testing. Subsequently, extension of the analysis software through the addition of additional relevant parameters and methods has to be designed and implemented. Through this supplement, the recommendations by advisors, including such agronomic factors as strategic cultivar selection, to farmers could be enhanced, and as a result agronomic risks in cereal production resulting from climate change impacts might be reduced [31,59].

Acknowledgments: We acknowledge funding for covering the costs of publishing with open access by the Justus-Liebig-University Giessen. We would like to thank Phillip Parker for English proofreading the manuscript.

Author Contributions: J.M. designed and performed the research. J.M. analyzed the data. J.M. and B.H. discussed the results, commented on the manuscript and wrote the paper.

Conflicts of Interest: The authors declare no conflict of interest.

\section{References}

1. IPCC: Final draft Report. Chapter 24. Asia. Available online: www.ipcc.ch/pdf/assessment-report/ar5/ wg2/drafts/fd/WGIIAR5-Chap24_FGDall.pdf (accessed on 17 February 2016).

2. Nelson, G.C.; Valin, H.; Sands, R.D.; Havlík, P.; Ahammad, H.; Deryng, D.; Elliott, J.; Fujimori, S.; Hasegawa, T.; Heyhoe, E.; et al. Climate change effects on agriculture: Economic responses to biophysical shocks. Proc. Natl. Acad. Sci. USA 2014, 111, 3274-3279. [CrossRef] [PubMed]

3. Ash, A.; McIntosh, P.; Cullen, B.; Carberry, P.; Smith, M. Constraints and opportunities in applying seasonal climate forecasts in agriculture. Aust. J. Agric. Res. 2007, 58, 952-965. [CrossRef]

4. Motha, R. Development of an agricultural weather policy. Agric. Forest Meterol. 2007, 142, 303-313. [CrossRef]

5. Wiebe, K.; Lotze-Campen, H.; Sands, R.; Tabeau, A.; van der Mensbrugghe, D.; Biewald, A.; Bodirsky, B.; Islam, S.; Kavallari, A.; Mason-D'Croz, D.; et al. Climate change impacts on agriculture in 2050 under a range of plausible socioeconomic and emissions scenarios. Environ. Res. Lett. 2015, 10, 85010. [CrossRef]

6. Pompe, S.; Hanspach, J.; Badeck, F.; Klotz, S.; Thuiller, W.; Kühn, I. Climate and land use change impacts on plant distributions in Germany. Biol. Lett. 2008, 4, 564-567. [CrossRef] [PubMed] 
7. Wechsung, F.; Gerstengarbe, F.W.; Lasch, P.; Lüttger, A. Die Ertragsfähigkeit deutscher Ackerflächen unter Klimawandel. Available online: www.pik-potsdam.de/glowa/pdf/bvvg/zusammenfassung11_9.pdf (accessed on 17 February 2016).

8. Potsdam Institute for Climate Impact Research. Report No. 128. Available online: https://www.pikpotsdam.de/research/publications/pikreports/.files/pr128.pdf (accessed on 4 May 2016).

9. Kassie, B.T.; Hengsdijk, H.; Rötter, R.; Kahiluoto, H.; Asseng, S.; van Ittersum, M. Adapting to climate variability and change: Experiences from cereal-based farming in the central rift and Kobo Valleys, Ethiopia. Environ. Manag. 2013, 52, 1115-1131. [CrossRef] [PubMed]

10. Menapace, L.; Colson, G.; Raffaelli, R. Climate change beliefs and perceptions of agricultural risks: An application of the exchangeability method. Glob. Environ. Chang. 2015, 35, 70-81. [CrossRef]

11. Dinar, A.; Mendelssohn, R. Handbook on Climate Change and Agriculture; Edward Elgar Publishing: Cheltenham, UK, 2011.

12. Gornall, J.; Betts, R.; Burke, E.; Clark, R.; Camp, J.; Willett, K.; Wiltshire, A. Implications of climate change for agricultural productivity in the early twenty-first century. Philosophical transactions of the Royal Society of London. Ser. B Biol. Sci. 2010, 365, 2973-2989. [CrossRef] [PubMed]

13. Porter, J.R.; Xie, L.; Challinor, A.J.; Cochrane, K.; Howden, H.M.; Iqbal, M.M.; Lobell, D.B.; Travasso, M.I. Food security and food production systems. In Climate Change 2014: Impacts, Adaptation and Vulnerability; Barros, C.B., Dokken, V.R., Eds.; Cambridge University Press: Cambridge, UK, 2014; pp. 485-533.

14. Howden, S.M.; Soussana, J.-F.; Tubiello, F.N.; Chhetri, N.; Dunlop, M.; Meinke, H. Adapting agriculture to climate change. Proc. Natl. Acad. Sci. USA 2007, 104, 19691-19696. [CrossRef] [PubMed]

15. Reidsma, P.; Ewert, F.; Lansink, A.O.; Leemans, R. Adaptation to climate change and climate variability in European agriculture: The importance of farm level responses. Eur. J. Agron. 2010, 32, 91-102. [CrossRef]

16. Swe, L.M.M.; Shrestha, R.P.; Ebbers, T.; Jourdain, D. Farmers' perception of and adaptation to climate-change impacts in the dry zone of Myanmar. Clim. Dev. 2014, 7, 437-453. [CrossRef]

17. Smit, B.; Skinner, M.W. Adaptation options in agriculture to climate change: A typology. Mitig. Adapt. Strateg. Glob. Chang. 2002, 7, 85-114. [CrossRef]

18. Abid, M.; Schilling, J.; Scheffran, J.; Zulfiqar, F. Climate change vulnerability, adaptation and risk perceptions at farm level in Punjab, Pakistan. Sci. Total Environ. 2016, 547, 447-460. [CrossRef] [PubMed]

19. Ahmad, M.; Iqbal, M.; Khan, M.A. Climate Change, Agriculture and Food Security in Pakistan: Adaptation Options and Strategies. Available online: http://pide.org.pk/pdf/Advertisements/MPhil\%20Fellowship\% 20\%2013\%20Feb\%2014.pdf (accessed on 6 July 2016).

20. Stratonovitch, P.; Semenov, M.A. Heat tolerance around flowering in wheat identified as a key trait for increased yield potential in Europe under climate change. J. Exp. Bot. 2015, 66, 3599-3609. [CrossRef] [PubMed]

21. Rial-Lovera, K.; Davies, W.P.; Cannon, N. Implications of climate change predictions for cropping and prospects for possible mitigation: A review of challenges and potential responses. J. Sci. Food Agric. 2016. [CrossRef] [PubMed]

22. Federal Plant Vartiety Office. Descriptive Variety List. Available online: http:/ /www.bundessortenamt.de/ internet30/index.php?id=20\&L=1 (accessed on 3 May 2016).

23. Ahlemeyer, J.; Friedt, W. Winterweizenerträge in Deutschland Stabil Auf Hohem Niveau—Welchen Einfluss Hat Der Züchtungsfortschritt; DLG AgroFood Medien GmbH: Bonn, Germany, 2012; pp. 38-41.

24. Mackay, I.; Horwell, A.; Garner, J.; White, J.; McKee, J.; Philpott, H. Reanalyses of the historical series of UK variety trials to quantify the contributions of genetic and environmental factors to trends and variability in yield over time. Theor. Appl. Genet. 2011, 122, 225-238. [CrossRef] [PubMed]

25. Sylvester-Bradley, R.; Kindred, D.R. Analysing nitrogen responses of cereals to prioritize routes to the improvement of nitrogen use efficiency. J. Exp. Bot. 2009, 60, 1939-1951. [CrossRef] [PubMed]

26. Porter, J.R.; Semenov, M.A. Crop responses to climatic variation. Philosophical transactions of the Royal Society of London. Ser. B Biol. Sci. 2005, 360, 2021-2035. [CrossRef] [PubMed]

27. Newton, A.C.; Johnson, S.N.; Lyon, G.D.; Hopkins, D.W.; Gregory, P.J. Impacts of Climate Change on Arable Crops-Adaptation Challenges; Proceedings Crop Protection in Nothern Britain: Dundee, Scotland, 2008.

28. Kaya, Y.; Ozer, E. Parametric stability analyses of multi-environment yield trials in Triticale (xTriticosecale wittmack). Genetika 2014, 46, 705-718. [CrossRef]

29. Becker, H.C.; Leon, J. Stability analysis in plant breeding. Plant Breed. 1988, 101, 1-23. [CrossRef] 
30. Kang, M.S. Using genotype-by-environment interaction for crop cultivar development. Adv. Agron. 1998, 62, 199-252.

31. Mohebodini, M.; Dehghani, H.; Sabaghpour, S.H. Stability of performance in lentil (Lens culinaris Medik) genotypes in Iran. Euphytica 2006, 149, 343-352. [CrossRef]

32. Parry, M.A.J.; Hawkesford, M.J. An integrated approach to crop genetic improvement. J. Integr. Plant Biol. 2012, 54, 250-259. [CrossRef] [PubMed]

33. Dockter, C.; Hansson, M. Improving barley culm robustness for secured crop yield in a changing climate. J. Exp. Bot. 2015, 66, 3499-3509. [CrossRef] [PubMed]

34. Leegood, R.C.; Evans, J.R.; Furbank, R.T. Food security requires genetic advances to increase farm yields. Nature 2010, 464, 831. [CrossRef] [PubMed]

35. Germany's National Meteorological Service. German Climate Atlas. Available online: http://www.dwd.de/ EN/ourservices/germanclimateatlas/germanclimateatlas.html (accessed on 4 May 2016).

36. Federal Statistical Office. GENESIS Database. Available online: https://www-genesis.destatis.de/genesis/ online (accessed on 4 May 2016).

37. Gurrath, P. Landwirtschaft auf einen Blick. Available online: www.destatis.de/DE/Publikationen/ Thematisch/LandForstwirtschaft/Querschnitt/BroschuereLandwirt-schaftBlick.html (accessed on 4 May 2016).

38. German Farmers' Association. Situation Report 2015/2016. Available online: http://www.bauernverband. de/situationsbericht-2015-16 (accessed on 4 May 2016).

39. Atteslander, P. Methoden der empirischen Sozialforschung, 13th ed.; Erich Schmidt Verlag: Berlin, Germany, 2010.

40. Kornmeier, M. Wissenschaftstheorie Und Wissenschaftliches Arbeiten; Physica-Verl.: Heidelberg, Germany, 2007.

41. Couper, M. Review: Web Surveys: A Review of Issues and Approaches. Public Opin. Q. 2000, 64, 464-494. [CrossRef] [PubMed]

42. Matsuo, H.; McIntyre, K.P.; Tomazic, T. The Online Survey: Its Contributions and Potential Problems; Survey Research Methods: Toronto, Canada, 2004.

43. Gosling, S.D.; Vazire, S.; Srivastava, S.; John, O.P. Should we trust web-based studies? A comparative analysis of six preconceptions about internet questionnaires. Am. Psychol. 2004, 59, 93-104. [CrossRef] [PubMed]

44. Arbuckle, J.G.; Morton, L.W.; Hobbs, J. Understanding farmer perspectives on climate change adaptation and mitigation: The roles of trust in sources of climate information, climate change beliefs, and perceived risk. Environ. Behav. 2015, 47, 205-234. [CrossRef] [PubMed]

45. Barnes, A.P.; Islam, M.; Toma, L. Heterogeneity in climate change risk perception amongst dairy farmers: A latent class clustering analysis. Appl. Geogr. 2013, 41, 105-115. [CrossRef]

46. Islam, M.M.; Barnes, A.; Toma, L. An investigation into climate change scepticism among farmers. J. Environ. Psychol. 2013, 34, 137-150.

47. Eitzinger, J.; Kersebaum, K.C.; Formayer, H. Landwirtschaft im Klimawandel. In Auswirkungen Und Anpassungsstrategien Für Die Land-Und Forstwirtschaftlichen Betriebe in Mitteleuropa; AgriMedia: Clenze, Germany, 2009.

48. Parker, P.; Ingwersen, J.; Högy, P.; Priesack, E.; Aurbacher, J. Simulating regional climate-adaptive field cropping with fuzzy logic management rules and genetic advance. J. Agric. Sci. 2016, 154, 207-222. [CrossRef]

49. Macholdt, J. Zur Sortenbewertung von Winterroggen Und Winterweizen Unter Standortbedingungen Im Nordostdeutschen Tiefland. Ph.D. Thesis, Humboldt-Universität zu Berlin, Berlin, Germany, March 2013.

50. Asrat, S.; Yesuf, M.; Carlsson, F.; Wale, E. Farmers' preferences for crop variety traits: Lessons for on-farm conservation and technology adoption. Ecol. Econ. 2010, 69, 2394-2401. [CrossRef]

51. Godfray, H.C.J.; Beddington, J.R.; Crute, I.R.; Haddad, L.; Lawrence, D.; Muir, J.F.; Pretty, J.; Robinson, S.; Thomas, S.M.; Toulmin, C. Food security: The challenge of feeding 9 billion people. Science 2010, 327, 812-818. [CrossRef] [PubMed]

52. Federal Ministry for the Environment, Nature Conservation, Building and Nuclear Safety. Gesetz zur Regelung der Gentechnik (Gentechnikgesetz-GenTG). Available online: http:/ / www.gesetze-im-internet. de/bundesrecht/gentg/gesamt.pdf (accessed on 4 May 2016).

53. Macholdt, J.; Honermeier, B. Variety choice in crop production for climate change adaptation: Farmer evidence from Germany. Outlook Agric. 2016, 45, 117-123. [CrossRef]

54. Longin, C.F.H.; Mühleisen, J.; Maurer, H.P.; Zhang, H.; Gowda, M.; Reif, J.C. Hybrid breeding in autogamous cereals. Theor. Appl. Genet. 2012, 125, 1087-1096. [CrossRef] [PubMed] 
55. Paschold, A.; Jia, Y.; Marcon, C.; Lund, S.; Larson, N.B.; Yeh, C.-T.; Ossowski, S.; Lanz, C.; Nettleton, D.; Schnable, P.S.; et al. Complementation contributes to transcriptome complexity in maize (Zea mays L.) hybrids relative to their inbred parents. Genome Res. 2012, 22, 2445-2454. [CrossRef] [PubMed]

56. Arnchen, C.; Dierauer, H. Hybrid Varieties in Organic Cereals? Prospects and Acceptance of Hybrid Breeding for Organic Production. Available online: www.orgprints.org/5097/1/Arncken-2005-Hybridenbericht.pdf (accessed on 7 May 2016).

57. Mühleisen, J.; Piepho, H.-P.; Maurer, H.P.; Longin, C.F.H.; Reif, J.C. Yield stability of hybrids versus lines in wheat, barley, and triticale. TAG. Theoretical and applied genetics. Theor. Und Angew. Genet. 2014, 127, 309-316. [CrossRef] [PubMed]

58. Macholdt, J.; Barthelmes, G.; Ellmer, F.; Baumecker, M. Eco-stability of winter rye varieties under site conditions of Brandenburg. J. Cultiv. Plants 2013, 65, 217-226.

59. Friedt, W.; Link, K. Klimawandel als Herausforderung-Entwicklung und Nutzung Stresstoleranter Sorten Für Nahrung und Energie; Ansätze der Züchtung auf Stresstoleranz. Vorträge für Pflanzenzüchtung: Bonn, Germany, 2007; pp. 69-77.

60. Longin, C.F.H.; Gowda, M.; Mühleisen, J.; Ebmeyer, E.; Kazman, E.; Schachschneider, R.; Schacht, J.; Kirchhoff, M.; Zhao, Y.; Reif, J.C. Hybrid wheat: Quantitative genetic parameters and consequences for the design of breeding programs. TAG. Theoretical and applied genetics. Theor. Und Angew. Genet. 2013, 126, 2791-2801. [CrossRef] [PubMed]

61. Michel, V.; Zenk, A. Eignung von Winterweizensorten unter speziellen Anbaubedingungen und Einführung neuer Parameter zur Bewertung von Sorten unter besonderer Berücksichtigung klimatischer Veränderungen. Available online: www.landwirtschaft-mv.de/cms2/LFA_prod/LFA/content/de/Fachinformationen/ Sorten/index.jsp (accessed on 17 February 2016).

62. Macholdt, J.; Barthelmes, G.; Ellmer, F.; Baumecker, M. Yield stability of winter wheat grown in Brandenburg. J. Cultiv. Plants 2013, 65, 411-421.

63. Laidig, F.; Piepho, H.-P.; Drobek, T.; Meyer, U. Genetic and non-genetic long-term trends of 12 different crops in German official variety performance trials and on-farm yield trends. Theor. Appl. Genet. 2014, 127, 2599-2617. [CrossRef] [PubMed]

64. Mühleisen, J.; Piepho, H.-P.; Maurer, H.P.; Reif, J.C. Yield performance and stability of CMS-based triticale hybrids. TAG. Theoretical and applied genetics. Theor. Und Angew. Genet. 2015, 128, 291-301. [CrossRef] [PubMed]

65. Mühleisen, J.; Maurer, H.P.; Stiewe, G.; Bury, P.; Reif, J.C. Hybrid breeding in barley. Crop Sci. 2013, 53, 819-824. [CrossRef]

66. ProWeizen. Research and Breeding Alliance for Increasing Yield in Wheat. Available online: http://www. proweizen.de/startseite/ (accessed on 4 May 2016).

67. Coors, J.G.; Pandey, S. The Genetics and Exploitation of Heterosis in Crops; American Society of Agronomy, Crop Science Society of America: Madison, WI, USA, 1999.

68. Whitford, R.; Fleury, D.; Reif, J.C.; Garcia, M.; Okada, T.; Korzun, V.; Langridge, P. Hybrid breeding in wheat: Technologies to improve hybrid wheat seed production. J. Exp. Bot. 2013, 64, 5411-5428. [CrossRef] [PubMed]

69. Kempe, K.; Rubtsova, M.; Gils, M. Split-gene system for hybrid wheat seed production. Proc. Natl. Acad. Sci. USA 2014, 111, 9097-9102. [CrossRef] [PubMed]

70. Federal Plant Variety Office. Guideline for Variety Testing Procedure. Available online: www. bundessortenamt.de/internet30/fileadmin/Files/PDF/Richtlinie_LW2000.pdf (accessed on 20 March 2016).

(C) 2016 by the authors; licensee MDPI, Basel, Switzerland. This article is an open access article distributed under the terms and conditions of the Creative Commons Attribution (CC-BY) license (http://creativecommons.org/licenses/by/4.0/). 